\title{
On the Teaching Quality Assurance of Talents Training for Chinese- Foreign Educational Joint Program
}

\author{
Haiying Ma \\ School of Economics, Northwest University for Nationalities, Lanzhou (730124), P.R.China, \\ Ixmahaiying8888@163.com
}

Keywords: Chinese-foreign educational programs; Talents training; Teaching assurance

\begin{abstract}
The Chinese-foreign educational joint program have provided important platforms for promoting the competitive power of Chinese higher education and educating internationalized talents, There is a very close relationship between the teaching quality assurance and the other four aspects including philosophy of education, teaching resources, assessment systems and faculty while there still exists much difference between the educational ideas and quality ideas. As the first joint program in Gansu, the Chinese-Foreign Bachelor's Degrees Project in International Economics and Trade Between Northwest University for Nationalities \&Utah State University was launched in 2012 with the purposes of adopting many foreign curricula systems and researches to ensure the frame of students education. Furthermore, an ultimate system aiming at ensuring the teaching quality and assessment is to be established.
\end{abstract}

\section{Introduction}

Since the beginning of 1980s, under the impetus of the policy of opening to the outside world, the internationalization of higher education has entered a sound development track. In 1985, the CPC Central Committee on Education System Reform Decision to Chinese Education Reform and Development Program issued in 1995, the State Education Commission promulgated the Interim Provisions of Sino-foreign cooperative education, provides a legal basis for the higher education internationalization, Sino-foreign cooperative education has been developing rapidly. In 2001, China's accession to the world trade organization, the international demand for talent to further increase. In 2003, the State Council promulgated the Regulations on the Administration of Chinese foreign Cooperation Programs in People's Republic of China, which was the first administrative law and regulation concerning Chinese-foreign cooperation program. In 2004, the Ministry of Education issued the measures for the implementation of the regulations of the People's Republic of China on Chinese foreign cooperation program. The two regulations promulgated in the early twenty-first Century provided legal protection for the Sino-foreign cooperations and made it into a new stage.

In 2005, the Ministry of education in China's reform and development of education initiatived, explicitly to strengthen the management of Chinese foreign cooperation program, standardize Sino foreign cooperation program. In 2010, with the National Long-term Education Reform and Development Plan (2010-2020) promulgated, Sino-foreign cooperative education ushered in a new development opportunity. As new higher education planing after China's reform and opening up, Sino-foreign cooperation program has been developed for several decades. As the inevitable product of the internationalization and globalization of the world education, the form of Sino foreign cooperation program is an important platform for the promotion of international competitiveness of higher education and the cultivation of international talents.

In the past ten years, Sino-foreign cooperations has become an increasingly important area of higher education. Especially after 2010, all kinds of research papers increased significantly. As of April 2014, the Chinese Journal Database (CNKI) has more than 2000 articles on Sino-foreign cooperation program. Domestic research on the subject of some papers mainly focus on Sino foreign cooperative education development mode and the significance, the introduction of high-quality foreign educational resources and utilization, educational concept and experience of empirical 
research, Sino-foreign cooperative education student management, teacher development and personnel training mode.

\section{The Current Situation and Problems of the Teaching Quality Assurance.}

For any type of personnel training, teaching quality is always the top priority. The correct concept of the quality of talent is conducive to the establishment of a sound model of personnel training, more conducive to the allocation of the corresponding teaching staff and teaching equipment, helping to promote the formation of scientific and standardized teaching quality assurance system. In the practice of running a school, the main partners in Sino-foreign cooperations generally come from the United States, Canada, Britain, Australia, New Zealand, France, Germany, Holland, Italy and other countries, which will inevitably involve the national cooperative education system and education idea. The concept of quality education and cooperation between the two sides there are differences, Sino-foreign cooperative education project operation, foreign on the teaching quality of the control is prone to poor convergence, loss of information and cooperation are disjointed. Especially in the face of the new model of personnel training, new problems, new challenges, it is easier to highlight the teaching quality assurance system vulnerabilities.

The quality of personnel training is one of the basic elements in the practice of higher education. Under the background of higher education popularization, Sino-foreign cooperative education is developing rapidly, for this type of project operation of colleges and universities, how to guarantee the quality of talent training is undoubtedly important factors to the success of the project. The quality of teaching is of great help to standardize the running of colleges and universities. The remarkable quality of personnel training is more conducive to the economic and social benefits of colleges and universities, to stimulate the vitality of the school, to encourage the teaching and management of the work force. From the current situation, the outstanding problems in the teaching quality assurance:

The Unfulfillment of Concept and Consciousness by the Decision Makers. From the internal aspects of University, because of the need of survival and development of the Sino-foreign cooperative education project decision makers is committed to expanding the scale of higher education and improving the running influence in the educational process, enhance the brand value, pay more attention to educational input-output efficiency. Overall, the short-term strategy is less than long-term one. The concept and consciousness of teaching quality assurance is particularly easy to be ignored.

The Lack of Quality Teaching Resources. International education resources usually refers to the international well-known colleges and universities, the advantages of general colleges and professional disciplines, institutions in general not well-known but need at home and professional disciplines, the domestic need is advanced and the characteristics of the curriculum and teaching materials, foreign educational institutions and their characteristics and successful management experience, with advanced and characteristic the teaching philosophy, teaching methods, teaching methods, evaluation form or teacher training in advanced experience. In theory, the teaching resources of cooperative education programs should follow the teaching outline, courseware, teaching materials, teaching plan, evaluation system and so on. In view of the various educational practice, most of the current cooperative education project teaching resources constitutes the main foreign original teaching syllabus and teaching materials, we designed the syllabus and teaching materials, supplementary teaching materials, has not been able to truly complete the meaning of the use of high-quality teaching resources abroad. In addition, in the aspect of knowledge convergence and effective use of resources, the Chinese teachers and students in cooperative education programs also have difficulties in learning and mastering.

The Lack of Specialized Monitoring and Evaluation Systems. In the aspect of academic and professional settings, the actual situation of Sino foreign cooperative education project of school teachers, school facilities, resource transformation, subject characteristics, are often considered inadequate, resulting in the instability of the quality of personnel training. Compared with the mature 
undergraduate teaching quality evaluation system of the general colleges and universities, there is still a lack of specialized, targeted and scientific teaching quality monitoring and evaluation system. In the process of teaching quality management, the existing general undergraduate quality monitoring and evaluation system and procedure. The national level has not yet introduced the theory and practice of teaching quality monitoring and evaluation system.

The Improvement of Internationalizational Teachers and Management Team. First of all, from the point of view of teachers, as a cooperative education program of teachers, not only need to have good English level, it should be in line with international teaching professional background, teaching ideas, teaching methods and international perspective. Especially for foreign high-quality teaching resources understanding, understanding, teaching, interpretation and other related links, need to have better control ability.

Secondly, from the management team, the training mode of Sino-foreign cooperative education project of talent, the ideological awareness, behavior management, study skills, intercultural communicative competence has higher requirements; this is also the management team to put forward more challenges. On the whole, there are still many deficiencies in the construction of the two teams in the majority of cooperative education programs, and the reform and improvement of the teaching and management areas need to be solved urgently.

\section{The Construction of Teaching Quality Guarantee System for Chinese-foreign Program}

The quality of internationalized talents training is an important driving force for the development and expansion of Sino foreign cooperation program. The high degree of attention to the teaching quality of cooperative education conforms to the trend of quality win in the international higher education. On the other hand, construction of the training teaching quality guarantee system to ensure the teaching quality of Chinese foreign cooperation program, scientific and standardized international talents, adhere to the education quality, enhance the competitiveness of talent, promote the brand has the important influence.

To Improve the Quality Assurance. The essence of talent cultivation in higher education is to create a broad sense of international, international professional ability and innovation ability, a good level of cross-cultural communication, with international competitiveness of the special talents. The quality of internationalized talents training is the basic index to test the Sino-foreign cooperation program. Therefore, from the office of academic perspective, talent training quality assurance concept is the cooperation project of the soul, it embodies the culture of the project positioning, personnel training direction and characteristics of personalized education thinking. The advanced concept of quality of personnel training is helpful to the summary and generalization of teaching practice. Once the concept of quality is established, it will optimize the overall teaching design, clear the direction of personnel training, improve the quality of teaching, but also inspire teaching motivation. Therefore, for Chinese foreign cooperations leaders, school should start, constantly improve the quality of teaching guarantee concept, focus on cultivating international talents what? How to cultivate high-quality international talents? How to ensure the quality of personnel training?

To Optimize the Foreign Teaching Resources and Improve Teaching Design. Foreign teaching resources are the basic starting point of the overall teaching of cooperative education projects, which determine the basic direction and the main content of the whole process of teaching. At present, the foreign resources of cooperative education projects are: the original teaching materials, the original teaching plan and curriculum outline, the original courseware and network learning platform and other major modules.

Teaching Thinking. to critical thinking and creative thinking for the overall teaching design in the premise of western universities are quite different in the teaching system and idea, which led directly to the Chinese universities in the introduction of the overall teaching resources of foreign institutions will face many difficulties in the application of resources. As for the training of Chinese foreign cooperation program, we must attach great importance to the teaching of western countries 
The Application of Teaching Materials. to carry out the transformation and cohesion of foreign teaching resources. As the Chinese teaching team cooperation, deal with the original introduction of a series of curriculum system and teaching content, teaching plan, course outline, course description, original courseware and network teaching platform and module is improved, the students' learning habits, thinking characteristics, language proficiency, learning mode, propose the connection scheme study of bridge erection. Not only the overall copy of the teaching team to bring obstacles, more likely to lead to a decline in student learning.

Teaching and Learning Lethods. teacher-student two-way transformation advanced teaching methods and evaluation methods is essential to reflect the true value of excellent teaching resources of universities in developed countries have generally emphasize the cultivation of critical thinking and creative talent. Chinese foreign cooperation program should be out of the fixed thinking of traditional undergraduate training. The teaching of higher education in our country focuses on teachers, systematic teaching knowledge and theory. The students are accustomed to passive acceptance, lack of teacher-student interaction and collision. While training talents in the mode of Sino foreign cooperation program, teachers should not only pay attention to the change of their teaching methods, but also advocate the reform of students' learning styles. Teachers should adopt the teaching methods such as task-based teaching, case teaching, practice teaching, studio teaching and so on. On the other hand, should also help to enhance students' autonomous learning, independent analysis, problem solving ability, let the students try to more independent learning methods, such as personal report, group discussion, social practice investigation, simulated case etc.

Setting up a Special Teaching Quality mMonitoring and Evaluation System. In the Sino-foreign cooperations, the two main bodies of Chinese institutions and foreign institutions should establish their own teaching quality monitoring and evaluation system. In practice, it is not difficult to find, usually overseas colleges and universities the more perfect, mainly reflected in: the external auditor system, regular external audit system, credit conditions, course description and implementation, achievements appraisal. Relatively speaking, the Chinese cooperative institutions often lack a set of effective teaching quality monitoring system. As the operator of the project, the domestic colleges and universities should focus on the actual situation of cooperation program, put forward a series of highly targeted scientific indicators, establish and improve a set of teaching quality management system suitable for Chinese foreign cooperation program.

To Build an International Teaching Staff. to ensure the quality of teaching for cooperative education projects, the internationalization of the teaching staff is the fundamental guarantee for the quality of teaching and personnel training. Qualified teachers of Chinese foreign cooperation program not only have a solid language skills, professional ability, global vision, but also should have a high level of cross-cultural communication skills and good human literacy. First of all, for foreign teachers in the introduction of talent, scholars do in addition to the rich teaching experience, teaching experience, scientific research ability, dedication and spirit of cooperation should be more strict qualification certification, the introduction of high-quality foreign teachers with high standard, eliminate shoddy. In addition, to strengthen the training, so that it more detailed understanding of China's policy, culture, working mechanism, and enhance their sense of belonging to work in a cooperative project, improve the stability of the work.

Secondly, for the Chinese teachers, should pay attention to the introduction of a study or work background of teachers with high professional level, foreign language ability, and foreign universities, in order to fully understand the internationalization of teaching methods and techniques, for all English teaching. For the existing teaching staff, you can consider the creation of training opportunities, selected exchanges, commissioned training.

Finally, we should pay attention to the cooperation of Chinese and foreign teachers. In teaching, we should consciously promote the communication and cooperation between Chinese and foreign teachers and encourage cooperative teaching. On the one hand, to enhance the team spirit of foreign teachers, on the other hand, it is beneficial to the improvement of Chinese teachers' teaching ideas, teaching methods and foreign language level. 


\section{Conclusions}

Since twenty-first Century, Sino foreign cooperation program as one of the main forms of international talent training, in the face of great opportunities, but also need to deal with the challenges of personnel training quality. From survival to development, from extensive expansion to intensive growth, cultivate high-quality talents' quality is the key to sustainable development, and constantly improve the quality of teaching programs is the fundamental guarantee of talent cultivation. Under this premise, how to develop a set of scientific, sustainable and international standards of teaching quality assurance system is the focus of all decision-makers should be thinking.

\section{Acknowledgements}

This work is supported by Special Funds for Undergraduate Teaching Reform by Central University of Northwest Minzu University (Grant No: 10019153).

\section{References}

[1]Lin Jinhui, Sino foreign cooperation program: policy, management and quality assurance. Xiamen, Xiamen University press, 2013 (in Chinese).

[2] Philip Bach Duarte, Comparative higher education: knowledge, the University and development. Beijing, People's education press, 2001(3)26-135.

[3] He Zubin, Establishment of long term mechanism of teaching quality assurance in higher education institutions in the post evaluation period. China University Education, 3 (2009)69-71.

[4] Chen Yukun, Introduction to quality assurance system of higher education, Beijing, Beijing Normal University Press, 2004

[5] Liu Hong Wei, Analysis of the current situation and Development Countermeasures of Sino foreign cooperation program . Journal of Jilin Institute of Education, 6 (2006) 89-90.

[6] Jiang Fuling, Problems and Countermeasures of Sino foreign cooperation program. Forum on Contemporary Education, 5 (2007)

[7] Lin Jinhui, Liu Zhiping, Introduction and effective use of high quality education resources in Sino foreign cooperation program. Educational Research, 5(2007)

[8] Liu Min, Strengthening the quality control of cross border education and improving the quality of Chinese foreign cooperation program. Journal of Qingdao Technical College, 2006 (3)65-70.

[9] Buddha Zhaohui, The quality assurance system of Sino foreign cooperative universities construction of higher engineering education research. 2006 (6)111-120.

[10] Tan Xiangming, Evaluation of Sino foreign cooperation program in Shanghai, Chinese Higher Education Evaluation. 3(2003) 34-49. (in Chinese). 